\title{
Childhood Craniopharyngioma
}

National Cancer Institute

\section{Source}

National Cancer Institute. Childhood Craniopharyngioma. NCI Thesaurus. Code C7816.

A craniopharyngioma that occurs during childhood. The vast majority of cases are adamantinomatous craniopharyngiomas. Clinical signs and symptoms include endocrine deficiencies and visual disturbances. 